\title{
FEATURES OF TRADITIONS AND CUSTOMS OF THE CIRCASSIAN PEOPLE LIVING IN THE BLACK SEA REGIONS
}

\author{
(C) Angelika D. Kunupova, Yulia A. Petrova \\ Rostov State University of Economics, Rostov-on-Don, Russian Federation \\ science-almanac@mail.ru
}

There are peoples whose history reads like an exciting novel - there are so many dizzying twists and turns, vivid episodes and amazing events, unusual and interesting traditions. One of these peoples is the Circassians, the indigenous population mainly of the Northern Black Sea region: Karachay-Cherkessia, Adygea, Kabardino-Balkaria, as well as the Southern Black Sea region: Krasnodar and Stavropol regions. The lands where the Circassians lived were some of the best. These places are still incredibly good. They are resort areas. This people has a rather distinctive culture. Despite the tragic pages of history, this nation has fully retained its vividly expressed individuality. Circassian women have always embodied the ideals of beauty, and men have been the standard of masculinity. The public life of the Circassians is usually filled with rituals. Life is a whole chain of ceremonies for the Circassian people. This article examines the history, linguistic habits, peculiarities of traditions, as well as the customs and norms of the Circassians, which are enshrined in the unwritten code of Adyghe Khabze. Such vital topics of the Circassian people as courtship, marriage, death and burial are reflected in this study.

Key words: Circassians, traditions, customs, culture, language, norms.

\section{[А.Д. Кунупова, Ю.А. Петрова Особенности традиций и обычаев черкесского народа, прожи- вающего в районах Причерноморья]}

Есть народы, история которых читается как захватывающий роман - столько в ней головокружительных поворотов, ярких эпизодов и удивительных событий, необычных и интересных традиций. Один из таких народов - черкесы, коренное население в основном Северного Причерноморья: Карачаево-Черкесии, Адыгеи, Кабардино-Балкарии, а также Южного Причерноморья: Краснодарского и Ставропольского края. Земли, на которых жили черкесы, были одни из самых наилучших. Эти места и сейчас невероятно хороши. Они являются курортными зонами. Этот народ обладает достаточно самобытной культурой. Несмотря на трагические страницы истории, эта нация полностью сохранила свою ярко выраженную индивидуальность. Черкесские женщины всегда воплощали собой идеалы красоты, а мужчины были эталоном мужественности. Общественная жизнь черкесов обычно наполнена обрядами. Жизнь - это целая цепь церемоний для черкесского народа. В данной статье исследуется история, языковые привычки, особенности традиций, а также обычаи и нормы черкесов, которые закреплены в неписаном кодексе «Адыгэ Хабзе». Такие жизненно важные темы черкесского народа, как ухаживание, брак, смерть и похороны отражены в данном исследовании.

Ключевые слова: черкесы, традиции, обычаи, культура, язык, нормы.

Angelika D. Kunupova - Student, Rostov State University of Economics, Rostov-on-Don, Russian Federation.

Yulia A. Petrova - Ph.D. in Philosophy, Associate Professor, Rostov State University of Economics, Rostovon-Don, Russian Federation.

Кунупова Анжелика Даутовна - студентка, Ростовский государственный экономический университет, е. Ростов-на-Дону, Российская Федерация.

Петрова Юлия Андреевна - кандидат философрских наук, доцент, Ростовский государственный экономический университет, г. Ростов-на-Дону, Российская Федерация.

According to legend, when God created the Earth, he carried all the mountains in a sack to distribute them over the earth. A hole was cut in his sack and all the mountains fell in one place between the Black Sea and the Caspian Sea. So, God has made this earth the only place in the world where the devil cannot penetrate and make its people evil, be- 
cause life will be hard enough for them as it is. It is from these mountains that the Circassians originate, known for their beauty, symmetry of forms, horsemanship, longevity and impeccable manners.

The Circassians are an ancient people consisting of twelve tribes that have inhabited the mountains of the North Caucasus and along the Black Sea coast since time immemorial. For 100 years they held back the full might of the tsarist armies, preventing their colonial invasion. One Circassian was said to be ten times better than any other. They were best described by the great Russian poet Mikhail Lermontov, who wrote during the Russian-Caucasian wars: "The Circassians embody sad dreams. The Circassian hearth is their highest, but freedom, freedom for a person is greater than the world and the Motherland."

The term "Circassians" is a uniting term for numerous Adyghe subethnoses and their country (in the form of Circassia), later (1922) became the official name for a small subethnic group of Adyghes (Beslenevs and mainly Kabardins). They moved to Kuban back in $1804-$

1822, during the Caucasian War, in present-day Karachay-Cherkessia.

Our language is not only a basic definition of the properties and tools with which we engage in communicative processes, but also as a mechanism of thought formation and reflection of our consciousness that makes us active individuals of language production [3]. The Circassian language is a branch of the Northwest Caucasian language group. It is quite complex and has a number of unusual differences. For example, characterized by an excessive abundance of consonants and a lack of vowel sounds, where declension is minimized. There is no such thing as the pronoun "You" in Circassian language, as all members of a given nation are equal among themselves. The Circassian language has a vigesimal numeral system. That is, the count goes to thirty, and then twenty-ten one, two, three, two-twenty one, two, three, and so on. Circassian aristocrats in the olden days had their own "hunting language". It is also reported that there is a specific female language. The Cyrillic alphabet was not derived until the 1930s. Unfortunately, the Circassian language is no longer a compulsory subject for students. [4] Imagine that your native language becoming an elective course in your home country.

Circassian customs and norms are enshrined in the unwritten code "Adyghe Khabze". It includes both the rules of customary law and moral principles that guide the behaviour and standards of human life and society as a whole. A rigid and complex system of morality in doctrine developed to ensure strict discipline to protect the country from invaders who coveted the Circassian lands. In addition, the social niceties of etiquette facilitated interactions between people, and good human behavior ensured human survival and prosperity. The Code consisted of two sections: The first set out customary feudal law with all its ramifications, while the second set out traditional Adyghe etiquette. Adyghe Khabze served as the law for special courts and councils established to resolve disputes and issues, as well as to make binding decisions. This code has remained unchanged for centuries. Thus, Adyghe Khabeze was a kind of constitution of feudal Circassia.

Traditionally, the roots of etiquette can be traced back to the golden age of the Narts, when the basic rules were laid down. The manners and manners of the Narts, reflected in tradition and rich culture, were models that the Circassians had been diligently imitating for centuries.[5] The collective and individual attributes of these legendary heroes had from time immemorial shaped the code of conduct of Circassian society and shaped the chivalrous characters of its nobility. These qualities included love of country and its defense to the last breath, deification of honor, care for people, courage, adherence to the code of chivalry, love for the clan and kin, loyalty to the bonds of comradeship and care for one's horse. Fundamental Principles of Adyghe Ethics: humanity, respect, honour and conscience were extended to the military sphere as well, considering it unacceptable to wage 
war without rules and respect for those principles. [7] Let us take a closer look at the traditions and customs of this proud mountainous people.

Circassians paid much attention to self-improvement, their beauty, and the symmetry of their children's physique. This cult-like preoccupation with physical perfection meant that for male children of princely and noble birth, a strict, almost rigorous, combat training regime was an integral part of the formative period. The use of leather straps and other devices to shorten the middle part of the body, created the ideal form in the folkloric ethnos: a lean torso and a broad chest. Thin waists, for both men and women, were at a premium. The costumes were created to emphasize the beauty of the body in accordance with generally accepted ideals. The Circassians were the trendsetters in the Caucasus. Their reputation for beauty and elegance was reflected in the famous saying "Dressed the Kabardin way".

One of the Circassian traditions preserved to this day is kashen. It's a friendship between young girls and guys who like each other. [2] According to the principle of kashen, a girl and a young man have many friends, they can visit each other within certain boundaries. Families allow this type of communication. This attitude also gives young people a chance to get to know each other. This tradition takes place among single girls and men in the premarital period and is limited by the laws of society. Circassian girls and boys try to get to know each other at weddings or in conversational settings. This encounter moves to a more serious level, which includes love and respect. And so, the young people become kashens for each other. Kashen is not allowed people of the same origin.

The abduction of girls has its own peculiarities in Circassian culture. A girl can run away without her family's knowledge in cases where she is certain that her family will reject her relationship for a variety of reasons. Sometimes this is done to eliminate formalities with the consent of the parties. In the Circassian community there are no marriages at a young age and no marriages by lineage from the same village or from the surrounding area. Families with certain kinship relations consider each other as brothers and sisters. Another reason for late marriage is the tradition of right of first marriage. In Circassian society, younger brothers are not allowed to marry before their elder ones. Another reason to wait is that spouses need to reach maturity, and understand the importance of marital responsibility.

Marriage and the associated traditions and festivities (dawe-dapshche) were the most difficult and enjoyable social affairs. A great number of rites, ceremonies, songs and dances have disappeared from Circassian life. Of course, some aspects were preserved, but the pomp and ceremony has been greatly diminished.

Ceremonies were held in three locations: the bride's father's house, the groom's father's house, and the house where the groom stays until the wedding night. Before the wedding, the Circassians paid for the bride kalym and considerable. (kalym - bride price) Such an expensive marriage is the reason for the custom that a widow is obliged to marry her deceased husband's brother. The same kalym preserves the sororate, according to which a widower must marry the sister of his deceased wife.

The young wife's position in her husband's family was shrouded in numerous prohibitions and conditions. A wife was not allowed to be near her husband in public places, and in the presence of older family members was not allowed to hold her husband's hands or hug his children, talk to her in-laws or even address them by name. After the wedding, the young wife was unable to go out for a year.

Divorce was a rarity in Circassian society. A strict moral code reduced the likelihood of marital infidelity. A woman who betrayed her husband had her hair cut off, her sleeves torn off, and was sent back to her father on horseback with her cuckold husband. 
Bigamy and polygamy were rare among the Circassians. The structure of society was firmly based on monogamy. Circassian women would rather break ties than be second on the list.

Childbirth among the Circassians. It was strictly forbidden to draw daggers or swords in the presence of a pregnant woman, as it was considered an evil omen. To protect the pregnant woman from evil spirits, she was not allowed to go to the cemetery, since then the child fell into an unconscious state. A pregnant woman was not allowed to blow out the fire, as then the baby would die from the fire. Women gave birth lying down on bedding made of stems and straw. If the birth was threatened by a dangerous disease, a ritual was performed. It consisted of a libation over a saber that was once used to shed blood. The blade was then placed under the headboard of the bed, and the consecrated drink was given to the woman. There were also other rituals that were performed to alleviate the suffering of childbirth and hasten it. [1] Men were strictly forbidden to enter the labour ward. At birth, he was immediately carried to the river, where he was bathed even in the freezing cold - cold water, according to the Circassians, even more hardened body and spirit. There were cases of death and then it was believed that the people, constantly at war, cannot afford an excessive number of weaklings. Thus, if a child died, it was considered a sacrifice for the good of the whole nation.

Infertility was believed to be related to supernatural forces that were in a woman's body. To expel evil spirits from a barren woman, a ritual called "Jumping Through the Fire" was performed. On the appointed day, people dressed in rags made fire in the holy grove. They believed that dirty clothes could ward off evil forces. During the procession to the bonfire, a young woman was showered with grain. Along the way they stopped to pay homage to Thagaled, the fertility deity. Thus, the supernatural being living in the girl's body was warned that it would be burned and asked to leave her body. The successful jump of the bride over the fire meant the complete cleansing of her body from evil spirits. The girl lived in her husband's house for about nine months after this ritual. If she did not become pregnant during this period, family members spoke in her presence: "The holy tree is fading".

Like all societies, Circassian funerals are held according to certain traditions. The duty to notify a relative of the funeral is assigned to a young man who is not related to the deceased. These young men are called "Ohako". The shroud in which the deceased is wrapped is made for women the same as for men. But the grave is dug for a woman - a little deeper. Reading the Quran in front of the deceased is obligatory. It is believed that the more loved ones and relatives do this, the better for the soul of the deceased. Mourning the deceased at a funeral is considered a kind of shame. There is only a mournful mood in the funeral hall. A funeral in a mourning mood without weeping or lamentation is another ritual form. Effendi is present at the funeral. He informs his relatives when they can say goodbye to the deceased and carry him out. Women do not go to the cemetery; they escort the deceased only to the gate. They may visit the cemetery only on the day appointed by the Effendi, when they clean the graves and put them in order. After the funeral, men do not shave for a week, but the closest to them until the 40th day, and women must wear dark clothing and scarves. In the deceased's house, the TV is not turned on for over a month. For thirty days after death, it is customary on Thursdays to roast Locumcakes in oil and hand out them to children. This can be done for a whole year or several years if you have the opportunity.

All of the above shows the important historical significance of the traditions and customs of Circassian national life in the Black Sea region that have been shaped over many centuries. The authority of everyday life was supported by the power of public opinion, that is why ancient customs and traditions were preserved and tested by time in a historically pristine form [6]. 
Based on the results of our research, it was concluded that the Circassians have an extensive range of traditions and customs that influence the development of the ethnos as a whole, taking its traditional origins from ancient times. These traditions and customs of the people influenced the development of the Circassian people as a whole and laid the foundation for this ethnos. Following traditions, the Circassian people have laid development programs that have potentially improved their lives and the life of the ethnos, uniting the nation and making it united in its views. The study also concluded that traditional structures and organised practices of Circassian customs contributed to the development and cohesion of the ethnos and the emergence of its distinctive culture.

\section{Лumepamypa}

1. Jaimoukhha A.M. Circassian Customs \& Traditions, Publisher: Centre for Circassian Studies, 2014, URL: https://circassianworld.com/pdf/Circassian_Customs_ and_Traditions.pdf (дата обращения: 12.09.2020)

2. Nurettin O. Turkey at the Beginning of 21st Century: Past and Present (pp.394-442). Edition: 1 Chapter: Demographic Development and Some Cultural Characteristics of Anatolian Circassians, Publisher: ST. KLIMENT OHRIDSKI UNIVERSITY PRESS, 2015 , URL: https://www.researchgate.net/publication/297403412_Demographic_Development_an d_Some_Cultural_Characteristics_of_Anatolian_Circassians (дата обращения: 08.09.2020)

3. Petrova Y.A. Language consciousness as the peculiarity of cultural differences. Журнал: Научный альманах стран Причерноморья. Издательство: Донской государственный технический университет (Ростов-на-Дону), №2 (6), 2016. С. 46-48, URL: http://science-almanac.ru/documents/86/2016-02-11-Petrova.pdf (дата обращения: 06.09.2020).

4. Sahin Z. Seven things to know about the Circassians - and their struggle, Publisher: TRT World, 2017, URL: HTTPS://WWW.TRTWORLD.COM/ASIA/7-THINGS-TOKNOW-ABOUT-THE-CIRCASSIANS-362964 (дата обращения: 10.09.2020)

5. Tesch N. Circassian people, Publisher: Encyclopaedia Britannica, 2017, URL: https://www.britannica.com/topic/Circassian (дата обращения: 03.09.2020).

6. Гадагатль А.A. Тема диссертации и автореферата: «Общественный быт адыгов в прошлом и настоящем, XVII-XX вв, Издательство: МП «Казачество», 1998, URL: https://www.dissercat.com/content/obshchestvennyi-byt-adygov-v-proshlom-inastoyashchem-xvii-xx-vv/read (дата обращения: 19.09.2020)

7. Марзей А. Статья: «Некоторые особенности черкесской (адыгской) цивилизации и традиционной этниеской культуры», Изадательтво: Адыгэ Хэку, 2014, URL: https://aheku.net/articles/russian/istoriya-adyigov/5598 (дата обращения: 03.09.20)

8. Энциклопедия Кавказа, Статья: “Очерк о гордом черкесском народе”, 2017, URL: https://tanci-kavkaza.ru/cherkesy/ (дата обращения: 15.09.2020)

\section{References}

1. Jaimoukhha A.M, Circassian Customs \& Traditions, Publisher: Centre for Circassian Studies, 2014, Available at: https://circassianworld.com/pdf/Circassian_Customs_ and_Traditions.pdf (accessed: 12 September 2020) 
2. Nurettin O. Turkey at the Beginning of 21st Century: Past and Present (pp. 394-442). Ed.: 1 Chapter: Demographic Development and Some Cultural Characteristics of Anatolian Circassians, Publisher: St. Kliment Ohridski University Press, 2015, Available https://www.researchgate.net/publication/297403412_Demographic_Development_an d_Some_Cultural_Characteristics_of_Anatolian_Circassians (accessed: 8 September 2020)

3. Petrova E.A. Yazykovoye soznaniye kak osobennost kulturnykh razlichiy [Language consciousness as the peculiarity of cultural differences]. Nauchnyy almanakh stran Prichernomorya. Rostov-na-Donu, No. 2 (6), 2016. pp. 46-48, Available at: http://science-almanac.ru/documents/86/2016-02-11-Petrova.pdf (accessed: 6 September 2020).

4. Sahin Z. Seven things to know about the Circassians - and their struggle, Publisher: TRT World, 2017, Available at: HTTPS://WWW.TRTWORLD.COM/ASIA/7-THINGSTO-KNOW-ABOUT-THE-CIRCASSIANS-362964 (accessed: 10 September 2020).

5. Tesch N. Circassian people, Encyclopaedia Britannica, 2017. Available at: https://www.britannica.com/topic/Circassian (accessed: 3 September.2020).

6. Gadagatl A.A. Tema dissertatsii i avtoreferata: «Obshchestvennyy byt adygov v proshlom i nastoyashchem, XVII-XX [The topic of the dissertation and the abstract: "Public life of the Circassians in the past and the present]. Izdatelstvo: MP «Kazachestvo». 1998. Available at: https://www.dissercat.com/content/obshchestvennyibyt-adygov-v-proshlom-i-nastoyashchem-xvii-xx-vv/read (accessed: 19 September 2020) (In Russian).

7. Marzey A. Nekotoryye osobennosti cherkesskoy (adygskoy) tsivilizatsii i traditsionnoy etniyeskoy kultury [Some features of the Circassian (Adyghe) civilization and traditional ethnic culture]. Adyge Kheku, 2014. Available at: https://aheku.net/articles/russian/istoriya-adyigov/5598 (accessed: 3 September 20) (In Russian).

8. Entsiklopediya Kavkaza, Ocherk o gordom cherkesskom narode [Encyclopedia of the Caucasus, Essay on the proud Circassian people], 2017, Available at: https://tancikavkaza.ru/cherkesyl (accessed: 15 September 2020) (In Russian). 